\title{
Alec Nove: 1915-1994
}

If the fraternity of Russian and east European scholars can be likened to a verdant human forest, one of the greatest (in my opinion, the greatest) of the oaks has fallen. Sunday, 15 May 1994 Alec and Irene Nove enjoyed an "absolutely lovely sail on a Norwegian fjord." That night, after having been taken to hospital, Alec succumbed to a massive heart attack.

Alec did his formal training at the London School of Economics, surely as Harold Laski's most famous student. During World War II Alec was a major in the British Army, in an intelligence unit. After the war, he returned to his post as a top level economist in the British civil service. Wise in its ways, in the fall of 1952, the government detailed him to the Glasgow Soviet Studies Institute. His major assignment was to analyze the Soviet political economy at his own pace. His primary responsibility was to send prepublication drafts of whatever he produced to London.

$\mathrm{I}$, too, was at the Glasgow Institute in fall 1952. We shared a table in a small room and I wrote my first two articles with Alec as co-author. The subject of our studies was the dismal performance of Soviet collectivized agriculture, an area of study in which he was to become a major contributor.

In 1958, Alec resigned from the civil service when he was called to be a reader in Russian Social and Economic Studies at the University of London. In 1962-1963 Alec was the Distinguished Visiting Rose Morgan Professor at the University of Kansas. Returning to the UK in fall 1963, the Noves moved north of the Tweed. Until his retirement a few years ago, he was professor of Economics at Glasgow University and, most importantly, the director of the Institute for Soviet and East European Studies.

Aleksandr Novakovsky was born in St. Petersburg in 1915. His father, Jacob, was of menshevik persuasion. His mother was a physician in that city. When he was seven years old his parents emigrated to England, where his father joined a Dutch firm trading with Russia, and Alec grew up to become the very model of a modern English intellectual, in the best sense of that term. Well, not quite, as he often noted over the years, his heart was really in the highlands, of "my adopted country." Scotland was not only his home for decades but it was the native land of his multi-talented wife, Irene. One of Alec's major delights was the annual holiday he and Irene took on one of the offshore Scottish islands.

Wherever he was, almost daily, Alec went for a brisk walk. Peter Wiles relates the following incident. The setting was the wind-swept streets of Moscow on a dreary, bitterly cold winter day. The Brezhnev stagnation had set in. The faces of the dour Muscovites treading the streets were particularly grim. Then, an apparition appeared. Approaching at a rapid pace was a Russian face that actually was smiling. As it came closer, the enigma was resolved. It was Alec!

Alec's sense of humor was world renowned. Of the many AAASS banquets I've attended, by far the one that was the most fun was the Washington, DC conference circa a decade ago. The before dinner speaker was Alec. He didn't really give a speech, he just kept us in stitches telling one after another of the one- and two-liners that he had picked up on his most recent visit to the USSR.

Over the decades Alec's pen produced scores of seminal papers on Soviet economic, political and social affairs. Most of all there are his books, monumental contributions to the understanding of Soviet affairs. They include The Economics of Feasible Socialism, Stalinism and After, The Soviet Economic System (several revisions and translated into eight languages) and Was Stalin Really Necessary? Any historian who attempts to unravel the mystery of the failed bolshevik attempt at creating communism must turn first to the collected works of Alec Nove.

Surely, there was no one in the profession who was more sought after as a visiting

Slavic Review 53, no. 4 (Winter 1994) 
professor at major university Russian and east European area centers (including Berkeley, Columbia, Harvard and Kansas). He was invited to give visiting lectures and participate in conferences on every continent (excluding Antarctica) and in most major nations. When the occasion called for it, his presentations were delivered in German, French, Italian, Spanish and, of course, impeccable Russian. However, he drew the line when he visited Japan. His presentation was in English.

As recorded in the Times (London), "he was elected a fellow of the British Academy in 1978, of the Royal Society of Edinburgh in 1982 and made an honorary fellow of the London School of Economics in the same year."

Fittingly, one of Alec's final, major, contributions was his piece, The Soviet System in Retrospect: An Obituary Notice, the Fourth annual Averell Harriman Lecture, Columbia University 1993. Space will not allow one to do justice here to the wisdom contained in that offering, but here are a few of the gems of his genius:

"Stalin was an Oriental despot, though also a modernizer with a hammer and sickle badge, compelled to cite Marx, but ready to kill anyone who truly believed Marxist doctrine." He eliminated so many who rose to high positions, because he did not "wish to see them coalesce into a new class."

"Khrushchev was still a campaigner, even a believer." Nevertheless his thaw "was not altogether a false spring. A part of the truth was told [e.g., his 'secret speech']. Furthermore, the terror itself was ended."

"Brezhnev was the quintessential Party functionary. Surely it was then that the party-state bureaucracy became a real ruling class..."

"So - enter Gorbachev and perestroika. He surely recognized the magnitude of the task. It is my conviction that history will treat his efforts more kindly than do his contemporaries....

Anyhow, Gorbachev failed. Perhaps the mix he was seeking between democracy and Party rule, between the market and planning was unattainable...."

Yeltsin's opposition "includes strange bedfellows," which Alec attributed to the peculiar history of "the remnants of the Communists and the Russian nationalists. We surely have not heard the last of them, especially the latter."

"What now? A new Time of Troubles, analogous to the anarchy that followed the death of Boris Godunov? Maybe." Speculating on the possible theme for the Harriman Lecture in the year 2,000 , Alec concluded by quoting the national poet of his adopted country, Robert Burns:

But mousie, thou art no' thy lane

In proving foresight may be vain.

The best-laid schemes of mice and men

Gang aft agley

And leave us naught but grief and pain

For promised joy.

Alec has joined the departed bards, but like them his wisdom remains for the ages yet to come.

ROY D. LAIRD

Professor Emeritus

Political Science and Russian and East European Studies

University of Kansas

August 1994 